\title{
Outbreak of equid herpesvirus 1 abortions at the Arabian stud in Poland
}

\author{
Karol Stasiak ${ }^{1}$, Magdalena Dunowska ${ }^{2}$ and Jerzy Rola ${ }^{*^{*}}$ (D)
}

\begin{abstract}
Background: Equid herpesvirus 1 (EHV-1) infections are endemic worldwide, including Poland. Many are subclinical, but some are associated with respiratory disease, abortion, neonatal foal death, or neurological disease. We describe an outbreak of abortions in Arabian mares at a well-managed State stud farm in Poland.

Case presentation: Eight of 30 pregnant mares aborted and one gave birth to a weak foal that died within $72 \mathrm{~h}$ after birth. EHV-1 was isolated from all fetuses as well as from the diseased foal. All viruses belonged to the $\mathrm{N}_{752}$ variant based on the predicted open reading frame (ORF) 30 amino acid sequence. All were identical to each other and to previous EHV-1 viruses from the same stud based on the ORF68 sequence analysis. The outbreak coincided with the lapse in the routine yearly EHV-1/4 vaccinations of the mares.
\end{abstract}

Conclusions: Multiple abortion due to EHV-1 infection can occur in well-managed groups of horses. Reactivation of latent EHV-1 in one of the resident mares followed by a horizontal spread was considered the most likely explanation for the outbreak. Routine vaccination is an important part of a herd-heath program.

Keywords: Abortions, Equid herpesvirus 1, EHV-1, Latency, ORF30, ORF68, PCR

\section{Background}

Respiratory tract infections with equid herpesvirus 1 (EHV-1) are common in horses. Although many such infections are subclinical, some can lead to serious economic losses [1]. The virus is classified in the family Herpesviridae, subfamily Alphaherpesvirinae and genus Varicellovirus. While sporadic cases of EHV-1 associated disease are fairly common, of most economic importance are outbreaks of abortions ("abortion storms") [2, 3], neonatal deaths [4] or neurological disease [5, 6] with multiple horses on one property affected.

Following primary infection horses are believed to become latently infected with EHV-1 for life [1]. During latency, viral genome is maintained in the episomal form in trigeminal ganglia or in T lymphocytes, without expression of structural genes and without production of infectious

\footnotetext{
*Correspondence: jrola@piwet.pulawy.pl

'Department of Virology, National Veterinary Research Institute, Al. Partyzantow 57, 24-100 Pulawy, Poland

Full list of author information is available at the end of the article
}

viruses [7-9]. The virus can periodically reactivate from latency, which may or may not be accompanied by disease. Consequently, it is difficult, if not impossible, to maintain EHV-1 free herd, but good management and infection control practises, coupled with vaccination, can substantially reduce the prevalence of abortion and neonatal foal death, and thus economic losses due to EHV-1 infection [10].

Diagnosis of EHV-1 abortion is based on clinical history, presentation, and detection of EHV-1 in fetal/neonatal tissues [11]. Gross pathological lesions may include icterus, hepatomegaly with necrotic foci, splenomegaly, subcutaneous or pulmonary oedema, presence of strawcoloured fluid in plural and abdominal cavities, as well as petechiation in the lungs and serosal or mucosal surfaces in other tissues [12], but severity of these lesions vary and some aborted fetuses may show no obvious gross lesions [11]. Detection of the virus in fetal tissues can be accomplished by polymerase chain reaction (PCR) [13-17], virus isolation in a variety of cell lines [18] or immunochistochemistry [19]. As PCR results can 
be available within hours of submission of diagnostic material to the laboratory, they usually form a basis for implementation of appropriate control measures [20, 21].

The key step in the pathogenesis of EHV-1 is its ability to establish cell-associated viraemia either after primary infection or during reactivation from latency [10]. A single nucleotide substitution at position 2254 (A to G) in the open reading frame (ORF) 30 gene, corresponding to the $\mathrm{N}$ to $\mathrm{D}$ substitution at amino acid position 752 of the viral DNA polymerase, has been proposed as a genetic marker for increased neurovirulence [22], although viruses with ORF30 $\mathrm{N}_{752}$ have also been detected from some cases of neurological disease [23]. The ORF30 $D_{752}$ viruses tend to establish viraemia of higher magnitude and longer duration than $\mathrm{N}_{752}$ viruses [24]. While the original virulent EHV-1 strain with $\mathrm{D}_{752}$ genotype (Ab4) was associated with development of both neurological disease and abortions, the majority of viruses obtained from abortion cases worldwide belonged to $\mathrm{N}_{752}$ genotype [22]. The same authors proposed that single-nucleotide polymorphisms observed in the region spanning approximately $600 \mathrm{bp}$ of ORF68 may provide a molecular marker for tracking the geographical origin of EHV-1. While the utility of ORF68 for this purpose has been subsequently challenged by some authors [25, 26], it may facilitate discrimination between the outbreak virus and other EHV-1 variants that circulate locally. Recently, a multi-locus analysis of the unique long region of EHV-1 has been suggested to provide a more comprehensive method of virus typing than ORF68 sequencing $[27,28]$.

In the present report we describe an abortion storm due to EHV-1 infection at one of the State stud farms in Poland.

\section{Case presentation}

\section{History}

From February to March 2017, multiple EHV-1 abortions occurred in a well-managed group of Arabian mares at one of the Polish State Studs. At the time, there were 30 pregnant mares (aged 5 to 18 years), 14 nonpregnant mares (aged 3 to 26 years), 25 yearlings, 31 two-years-olds and 17 stallions (aged 7 to 18 years) at the stud. At the beginning of November 2016 all pregnant mares were moved to their winter accommodation. The horses were kept in individual stalls, with some turnout time together in a shared paddock during the day. Non-pregnant mares were turned out in a separate paddock. Both paddocks were separated by hedges and a 7- $\mathrm{m}$ wide path which prevented direct contact between two groups of mares. Young horses (yearlings and twoyears-olds) were kept in a separate barn and turned out in the distant paddocks several hundred meters from where the mares were kept. The stud personnel consisted of seven to 10 grooms, each assigned to a different group of horses. Until 2015/2016 breeding season the herd health program included vaccination of all horses against equine rhinopneumonitis (Equip ${ }^{\circledR}$ EHV1, 4, Zoetis Poland), tetanus and equine influenza (ProteqFlu-Te, MERIAL, France), according to the manufacturer's recommendations. Despite routine vaccination, the stud had a history of occasional EHV-1 abortions. Most often, these were single abortion cases, except for 2012/13 breeding season, when four mares aborted over a period of 3 months, between January and March 2013, including mares I and F from the current outbreak. No EHV-1 abortions were recorded in 2013/2014, 2014/2015, and 2015/ 2016 breeding seasons. Due to change in management, none of the pregnant mares were vaccinated against rhinopenumonitis in 2016/2017 breeding season. Young horses from the stud routinely travelled to participate in a variety of sport events, as well as auction sales in Poland and abroad. These horses were kept separate from the pregnant mares at all times. In addition, all horses that returned from various events were quarantined for 2 weeks before being reintroduced to the resident population.

The first mare (A) aborted on February 12, 2017. The mare was immediately placed in strict isolation, and her stall in the main barn was thoroughly cleaned and disinfected. About a month later (March 9) two further mares (B and C) aborted within 2 days. On March 12, mare D gave birth to a weak foal with jaundice and respiratory disease that died 3 days later. Between March 16 and March 28 five further mares (E - I) aborted (Fig. 1). The aborting mares were reported to have a low-grade fever $\left(38.5-39.5^{\circ} \mathrm{C}\right)$ around the time of abortion by the stud's veterinarian, but no other premonitory clinical signs. There were no serious clinical complications recorded after the expulsion of fetuses.

\section{Pathology}

Complete necropsies were performed on eight aborted fetuses and the newborn foal by the attending veterinarian. All fetuses were fresh and enclosed within the fetal membranes. There were no apparent gross lesions in either the fetuses or placentas. Tissue samples (lung, liver, spleen, heart, and placenta) were submitted to the Department of Virology of the National Veterinary Research Institute in Pulawy (Poland) within $24 \mathrm{~h}$ of collection for laboratory investigation to identify the cause of abortion.

\section{Quantitative PCR}

On arrival at the laboratory, $2.0 \mathrm{~g}$ of each tissue was homogenised with $18 \mathrm{~mL}$ of Eagle Minimal Essential Medium (Sigma-Aldrich) supplemented with 1\% antibiotic solution (Sigma-Aldrich). Following a low-speed centrifugation, supernatants from tissues from the same fetus were pooled and stored at $-80^{\circ} \mathrm{C}$. DNA was extracted 


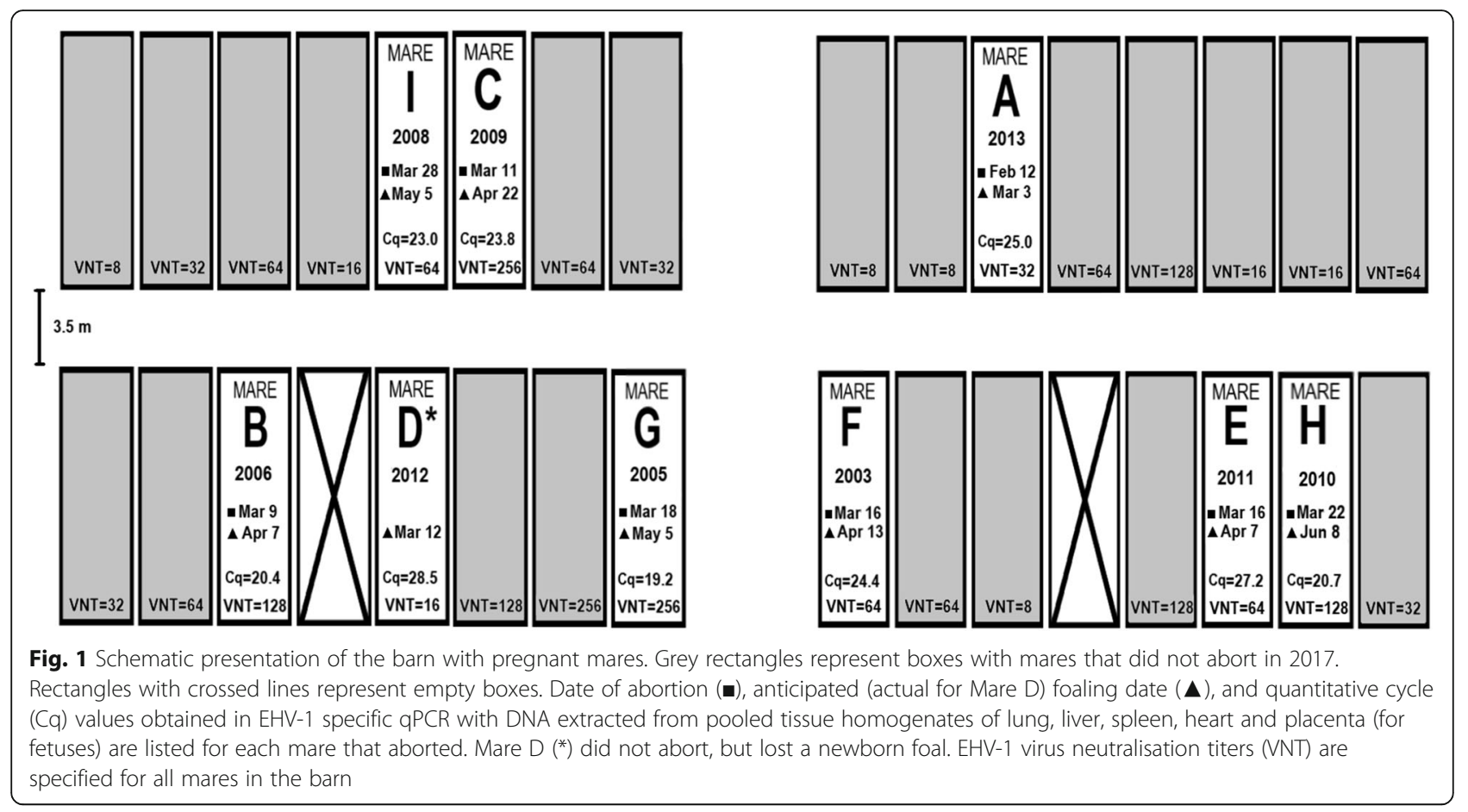

from $200 \mu \mathrm{L}$ of each pooled supernatant using QIAamp DNA Mini Kit (Qiagen, Germany) according to the manufacturer's recommendations and tested for the presence of EHV-1 and EHV-4 DNA using previously published primers from the conserved region of glycoprotein B [29, 30]. Positive (EHV-1 438/77 and EHV-4 405/76, American Type Culture Collection) and negative (water) controls were included in each PCR run. Samples were considered positive if the amplification curve crossed the threshold, as defined by automatic settings in the program (StepOne Plus $^{\text {Th }}$ Real-Time PCR System). All nine samples were positive for EHV-1, and none was positive for EHV-4 DNA.

\section{Virus isolation}

Pooled supernatants from tissue homogenates were used for virus isolation in rabbit kidney 13 cells as described previously [25]. All samples developed viral cytopathic effect within 2 to 6 days post inoculation. The identity of the viral isolates was confirmed by EHV-1 specific PCR $[29,30]$.

\section{Genotyping and phylogenetic analysis}

PCR assays to amplify fragments from ORF30 and ORF68 were performed as previously described [25]. A 380 bp ORF30 product was digested with SalI in order to distinguish between $\mathrm{N}_{752}$ and $\mathrm{D}_{752}$ variants based on restriction fragment length polymorphism (RFLP) [25]. In addition, PCR products were sent for sequencing to Genomed S.A. (Poland). The sequences were assembled using the BioEdit software (version 7.2.5) and analysed using MEGA 5.0.5.

Based on RFLP analysis of the ORF30 amplicon, all nine viruses from the stud belonged to ORF30 $\mathrm{N}_{752}$ genotype. This was further confirmed by sequencing. A phylogenetic tree of the 515-bp ORF68 gene fragment was reconstructed using the maximum likelihood method (ML) with 1000 bootstrap replicates using the Kimura 2-parameter model [31] in MEGA7 software [32] (Fig. 2). All nine ORF68 sequences were identical to each other and to four EHV-1 sequences (PL_2013_IV to VII) obtained from the abortion cases that occurred at the same stud in 2013 [25].

\section{GenBank accession numbers}

The nucleotide sequences of Polish EHV-1 described in this study were submitted to GenBank under the following accession numbers: MN193769 - MN193777 (ORF30) and MN193760 - MN193768 (ORF68).

\section{Serology}

Blood samples for serology were collected from all 30 mares in the barn once on April 18, 3 weeks after the last abortion case occurred. The presence of EHV-1 specific antibodies was determined using the virus neutralization test (VNT) according to the Manual of Diagnostic Tests and Vaccines for Terrestrial Animals protocol [33]. All serum samples were positive for EHV1 antibody, with titers ranging from 8 to 256 (Fig. 1). 


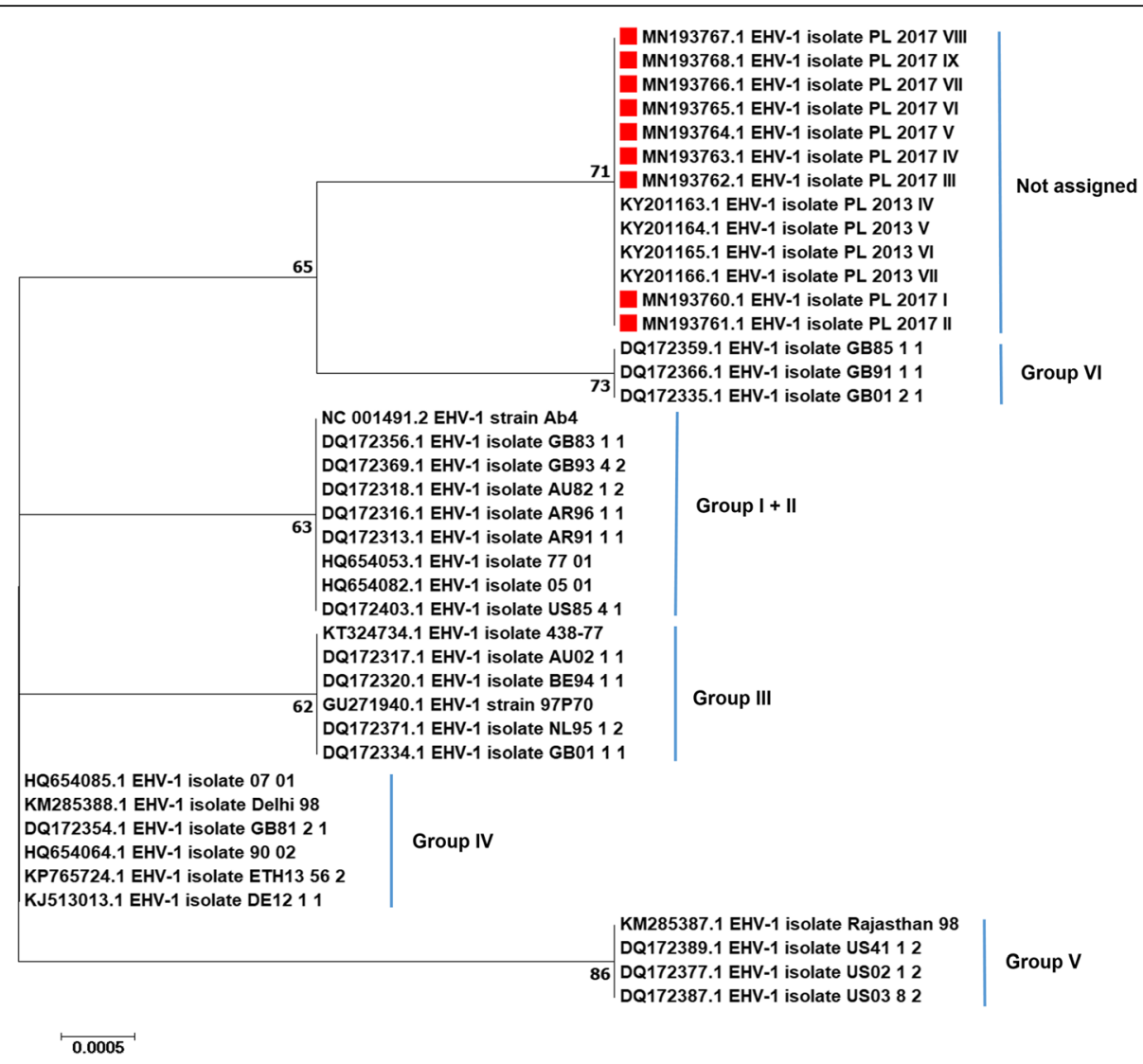

Fig. 2 Phylogenetic tree of equid herpesvirus-1 based on 515 bp fragment from the ORF68 gene. The evolutionary history was inferred by using the Maximum Likelihood method based on the Kimura 2-parameter model [31]. The tree with the highest log likelihood (-742.11) is shown. The percentage of trees in which the associated taxa clustered together is shown next to the branches. Initial tree(s) for the heuristic search were obtained automatically by applying Neighbor-Join and BioNJ algorithms to a matrix of pairwise distances estimated using the Maximum Composite Likelihood (MCL) approach, and then selecting the topology with superior log likelihood value. The tree is drawn to scale, with branch lengths measured in the number of substitutions per site. The analysis involved 41 nucleotide sequences including Polish EHV-1 sequences $(n=$ 13) and international sequences $(n=28)$ sourced from GenBank (accession numbers included in the figure). All positions containing gaps and missing data were eliminated. There were a total of 495 positions in the final dataset. Evolutionary analyses were conducted in MEGA7 [32]. The clusters were labelled as groups I - VI according to [22]. The sequences obtained in the current study are labelled with red rectangles

\section{Disease management and outcome}

Following the first three abortion cases, the following procedures were introduced:

- Disinfection mats were placed in front of the entrance to each stable.

- All movement of horses to and from the stud was suspended. In addition, the stud was closed to outside visitors.

- Mares that aborted were isolated from other horses for a period of 30 days following abortion.

- Staff movement between stables was restricted and only designated people were allowed to care for pregnant mares.

- Immediate introduction of EHV-1 vaccination of all horses.

- Foaling staff was required to use disposable coveralls and gloves when handling mares and foals.
- All stalls, stables and equipment routinely used at the stud were thoroughly cleaned and disinfected.

All mares that aborted were successfully covered and produced healthy foals in the following $(2017 / 18)$ breeding season.

\section{Discussion and conclusions}

Equid herpesvirus 1 is one of the common causes of infectious abortion in horses [34]. Typical for EHV-1 abortions, all mares described in this report aborted in the last trimester of pregnancy. The reason for this timing is not fully understood, but it may be linked to an increased susceptibility of uterine endothelial cells to EHV-1 infection in late pregnancy [35]. The virus infection of endothelial cells of blood vessels in the gravid uterus leads to severe vasculitis and multifocal thrombosis, which are thought to be responsible for abortion 
[35-37]. The expelled fetuses were fresh, without apparent gross lesions, which is consistent with reports by others [11]. It is possible that mild gross lesions (if present) may have been missed, as the necropsies were performed by the stud's veterinarian rather than a qualified pathologist. As the signalment was suggestive of EHV-1 involvement, virological investigation was instigated, which lead to detection of EHV-1 from tissues of aborted fetuses, and confirmed aetiological involvement of the virus.

The tissues used for virus detection/isolation included spleen, liver, lung, heart and placenta. The former three have been shown to contain the highest levels of the virus and are therefore considered to be preferred samples for testing [12]. Occasionally, abortion occurs due to placental insufficiency induced by virus infection before EHV-1 translocates to the fetus. On those rare occasions, the fetus may be virus-negative, which underscores the importance of testing placenta, if available [12].

Abortion storms are thought to result from horizontal transmission of EHV-1 between pregnant mares, but the initial source of the virus is often difficult to establish $[2,3]$. It may be a newly introduced horse with an active EHV-1 infection, but equally it could be reactivated virus from one of the resident horses. The latter was a more likely source of the virus in the current outbreak for several reasons.

Firstly, the pregnant mares had been resident at the stud for years, managed by experienced handlers and were separated from young stock and other horses. Hence, they were kept under conditions that minimized stress. The triggers for EHV-1 reactivation from latency are poorly understood, but it is generally believed that stressful conditions such as unsettled social structure, changes in the daily routine, travelling or participation in competitive events are likely to play a role in that process $[1,38]$. Secondly, it has been suggested that pregnant mares are predisposed to reactivation of EHV1 , which may be linked to physiological immunosuppression that is induced in the horse during pregnancy [39]. Lastly, the fact that all EHV-1 sequences obtained in the current study were identical to each other and to the four EHV-1 sequences obtained from the previous abortion cases at the same stud [25] also supports recrudescence of a latent infection, with the subsequent horizontal spread, as a likely source of the virus in the current outbreak.

Alternatively, EHV-1 with increased virulence may have been introduced to the stud from external sources during 2016/17 breeding season. We consider it less likely for several reasons. All horses were quarantined before introduction or re-introduction to the stud for a period of 2 weeks. Although EHV-1 DNA was occasionally detected in nasal secretions for up to 3 weeks following experimental infection [40], the majority of horses with active EHV-1 infection cease shedding the live virus within 1 to 2 weeks post infection [11, 17, 40-42]. Even if an occasional horse shed EHV-1 after being released from the quarantine, strict separation between pregnant mares and other horses should have minimized the chances of transmission of such virus to the mares.

Irrespective of the initial source of the virus, subsequent transmission of EHV-1 among pregnant mares led to the loss of pregnancies, including one death of a neonatal foal, for $9 / 30$ pregnant mares. It is likely that the virus had been circulating among horses at the stud in prior seasons, without any clinically important consequences. Such pattern of EHV-1 circulation between vaccinated mares and their foals was described in several Australian-based studies [43-46]. One notable feature of the current outbreak is the fact that it coincided with the lapse in the routine yearly EHV-1/4 vaccination of the mares. This suggests that vaccination of mares in the prior breeding seasons induced protective immunity that reduced the likelihood of abortions. The occurrence of an abortion storm in the first season when mares were not vaccinated against EHV-1 underscores the fact that duration of immunity following EHV-1 vaccination is thought to be short [47]. It also highlights the importance of including vaccination as part of a herd-health program, as it limits the severity of clinical disease as well as duration and magnitude of EHV-1 shedding [48]. However, efficacy of currently available EHV-1 vaccines vary and none of them prevent establishment of EHV-1 infection or latency $[46,47]$. Abortions can occur in the face of vaccination, as it happened at this stud in 2013, and has also been reported elsewhere [2, 46, 49]. Hence, vaccination should not be viewed as a substitute for good management practices including appropriate infection control measures.

All aborting mares described in this report showed mild fever at the time of abortion. This may have represented the first or second peak of biphasic fever typical for EHV1 infections. The first peak can occur as early as 1 to 2 days post infection and is hence considered to be one of the most consistent early signs of EHV-1 infection both under field [5, 50,51] and experimental [52] conditions. Consequently, implementation of temperature monitoring of all in-contact horses as early as possible in the outbreak situation is a common recommendation [38]. The febrile horses should be considered infectious and isolated from the rest of the population. Implementation of this control measure in the current outbreak may have minimised the number of abortion cases. It would have also provided some data on the infection status of the non-aborting mares, as blood samples or nasal swabs could have been collected from febrile horses for detection of the virus. Considering the close contact between mares at the turnout time, it is likely that most of the mares in the barn were infected with EHV-1, but only some aborted. This is 
supported by relatively high VNT titres $(\geq 64)$ in $10 / 21$ pregnant mares that did not abort. It is unlikely that such high titres represented residual titres from vaccination in the previous breeding season. Other control measures implemented at the stud including isolation of mares following abortions, control of traffic, use of personal protective equipment, hand washing, as well as cleaning and disinfection of stalls and equipment were likely to contribute to the control of the outbreak, consistent with recommendations of others $[10,50]$.

The VNT titres of the pregnant mares ranged from 8 to 256 , without any apparent differences between the titres of the mares that aborted and those that have not. This underscores the limited value of the VNT in investigations of EHV-1 induced abortions. Paired serum samples were not collected, which is a limitation of the study. However, it is often difficult to detect a fourfold rise in VNT titres between acute and convalescent samples, as the antibody titres may have already risen by the time abortion occurs and acute samples are collected $[2,20,53]$. Determination of levels of complement fixing antibody may have been more useful as an indication of recent infection, as these decline sooner following EHV-1 infection or recrudescence than $\mathrm{VN}$ antibodies [47, 53]. Other problems related to EHV-1 VNT include crossreaction with antibodies raised in response to EHV-4 infection [54], as well as lack of correlation between the levels of $\mathrm{VN}$ antibodies and protection from abortion [47]. Cell-mediated immune responses are believed to provide protective immunity $[47,55,56]$, but assessment of such responses is complex and beyond the typical capabilities of a diagnostic laboratory.

All the viruses described in the current report belonged to the ORF30 $\mathrm{N}_{752}$ genotype, consistent with the predominance of the $\mathrm{N}_{752}$ variants among EHV-1 abortion cases in Poland [25, 57] and other countries $[22,28,58]$. While data from a recent investigation in Ireland [27] suggested that viruses with $\mathrm{D}_{752}$ genotype were more likely not only to induce neurological disease, but also to be associated with multiple abortion cases as opposed to sporadic abortions, our results underscore the fact that infection with viruses of either $N_{752}$ or $D_{752}$ genotype should be considered equally important, and similar precaution/control measures should be implemented to minimise the economic losses due to disease outcomes associated with these infections.

\footnotetext{
Abbreviations

EHV-1: Equid herpesvirus 1; EHV-4: Equid herpesvirus 4; ORF30: Open reading frame 30; ORF68: Open reading frame 68; PCR: Polymerase chain reaction; RFLP: Restriction fragment length polymorphism; VNT: Virus neutralization test
}

\section{Acknowledgements}

We would like to acknowledge the stud's veterinarians and managers for providing the samples for testing as well as relevant information about the management of the mares.

\section{Authors' contributions}

KS: laboratory investigations, sequence analysis, data interpretation, manuscript preparation, MD: data analysis, manuscript preparation, JR: funding gaining, manuscript revision. All authors read and approved the final manuscript.

\section{Funding}

This research received no specific grant from any funding agency in the public, commercial or not-for-profit sectors.

\section{Availability of data and materials}

The data sets supporting the results of this article are included within the article.

\section{Ethics approval and consent to participate}

One of the roles of the National Veterinary Research Institute in Pulawy is monitoring endemic diseases among Polish livestock. Submission and processing of samples for this study was within the scope defined by this role. The samples were collected and submitted by the stud's veterinarian as part of a routine diagnostic investigation. The approval from ethics committee was not required according to national regulation ("Act on the Protection of Animals Used for Scientific or Educational Purposes" published in the Journal of Laws of 2015, item 266 from 15 January, 2015).

\section{Consent for publication}

Written informed consent for publication of clinical details of horses was obtained from the stud manager.

\section{Competing interests}

The authors declare that they have no competing interests.

\section{Author details}

${ }^{1}$ Department of Virology, National Veterinary Research Institute, Al. Partyzantow 57, 24-100 Pulawy, Poland. ${ }^{2}$ Institute of Veterinary, Animal and Biomedical Sciences, Massey University, Palmerston, North, New Zealand.

Received: 4 November 2019 Accepted: 22 September 2020

Published online: 06 October 2020

\section{References}

1. Slater J. Equine herpesviruses. In: Sellon DC, Long MT, editors. Equine infectious diseases. St. Louis: Saunders Elsevier; 2007. p. 134-53.

2. van Maanen C, Willink DL, Smeenk LA, Brinkhof J, Terpstra C. An equine herpesvirus 1 (EHV1) abortion storm at a riding school. Vet Q. 2000; 22(2):83-7.

3. Damiani AM, de Vries M, Reimers G, Winkler S, Osterrieder N. A severe equine herpesvirus type 1 (EHV-1) abortion outbreak caused by a neuropathogenic strain at a breeding farm in northern Germany. Vet Microbiol. 2014;172(3-4):555-62.

4. Frymus T, Kita J, Woyciechowska S, Ganowicz M. Foetal and neonatal foal losses on equine herpesvirus type $1(\mathrm{EHV}-1)$ infected farms before and after EHV-1 vaccination was introduced. Pol Arch Weter. 1986;26(3-4):7-14.

5. van Maanen C, Sloet van Oldruitenborgh-Oosterbaan MM, Damen EA, Derksen AG. Neurological disease associated with EHV-1-infection in a riding school: clinical and virological characteristics. Equine Vet J. 2001; 33(2):191-6.

6. Pronost S, Legrand L, Pitel PH, Wegge B, Lissens J, Freymuth F, et al. Outbreak of equine herpesvirus myeloencephalopathy in France: a clinical and molecular investigation. Transbound Emerg Dis. 2012;59(3):256-63.

7. Slater JD, Borchers K, Thackray AM, Field HJ. The trigeminal ganglion is a location for equine herpesvirus 1 latency and reactivation in the horse. J Gen Virol. 1994;75(8):2007-16.

8. Chesters PM, Allsop R, Purewal A, Edington N. Detection of latencyassociated transcripts of equid herpesvirus 1 in equine leukocytes but not in trigeminal ganglia. J Virol. 1997;71(5):3437-43.

9. Allen GP. Antemortem detection of latent infection with neuropathogenic strains of equine herpesvirus-1 in horses. Am J Vet Res. 2006;67(8):1401-5.

10. Kydd JH, Slater J, Osterrieder N, Lunn DP, Antczak DF, Azab W, et al. Third international Havemeyer workshop on equine Herpesvirus type 1. Equine Vet J. 2012;44(5):513-7. 
11. Gardiner DW, Lunn DP, Goehring LS, Chiang YW, Cook C, Osterrieder N, et al. Strain impact on equine herpesvirus type 1 (EHV-1) abortion models: viral loads in fetal and placental tissues and foals. Vaccine. 2012;30(46):6564-72.

12. Prickett ME. The pathology of disease caused by equine herpesvirus 1. In: Bryans JT, Gerber H, editors. Equine infectious diseases II Proceedings of the Second International Conference on Equine Infectious Diseases, Paris 1969. Basel: S. Karger; 1970. p. 24-33.

13. Borchers K, Slater J. A nested PCR for the detection and differentiation of EHV-1 and EHV-4. J Virol Methods. 1993;45(3):331-6.

14. Lawrence GL, Gilkerson J, Love DN, Sabine M, Whalley JM. Rapid, single-step differentiation of equid herpesviruses 1 and 4 from clinical material using the polymerase chain reaction and virus-specific primers. J Virol Methods. 1994;47(1-2):59-72.

15. Pusterla N, Hussey SB, Mapes S, Johnson C, Collier JR, Hill J, et al. Molecular investigation of the viral kinetics of equine Herpesvirus-1 in blood and nasal secretions of horses after corticosteroid-induced recrudescence of latent infection. J Vet Intern Med. 2010;24(5):1153-7.

16. Pusterla N, Hussey SB, Mapes S, Leutenegger CM, Madigan JE, Ferraro GL, et al. Comparison of four methods to quantify Equid herpesvirus 1 load by real-time polymerase chain reaction in nasal secretions of experimentally and naturally infected horses. J Vet Diagn Invest. 2009;21(6):836-40.

17. Hussey SB, Clark R, Lunn KF, Breathnach C, Soboll G, Whalley JM, et al. Detection and quantification of equine herpesvirus-1 viremia and nasal shedding by real-time polymerase chain reaction. J Vet Diagn Invest. 2006: 18(4):335-42.

18. Allen GP, Bryans JT. Molecular epizootiology, pathogenesis, and prophylaxis of equine herpesvirus-1 infections. Prog Vet Microbiol Immunol. 1986;2:78-144.

19. Schulman $M L$, Becker $A$, van der Merwe BD, Guthrie AJ, Stout TA. Epidemiology and reproductive outcomes of EHV-1 abortion epizootics in unvaccinated thoroughbred mares in South Africa. Equine Vet J. 2015;47(2):155-9.

20. Walter J, Seeh C, Fey K, Bleul U, Osterrieder N. Clinical observations and management of a severe equine herpesvirus type 1 outbreak with abortion and encephalomyelitis. Acta Vet Scand. 2013;55:19.

21. Slater JD, Lunn DP, Horohov DW, Antczak DF, Babiuk L, Breathnach C, et al. Report of the equine herpesvirus-1 Havermeyer workshop, San Gimignano, Tuscany, June 2004. Vet Immunol Immunopathol. 2006;111(1-2):3-13.

22. Nugent J, Birch-Machin I, Smith KC, Mumford JA, Swann Z, Newton JR, et al. Analysis of equid herpesvirus 1 strain variation reveals a point mutation of the DNA polymerase strongly associated with neuropathogenic versus nonneuropathogenic disease outbreaks. J Virol. 2006;80(8):4047-60.

23. Cuxson JL, Hartley CA, Ficorilli NP, Symes SJ, Devlin JM, Gilkerson JR. Comparing the genetic diversity of ORF30 of Australian isolates of 3 equid alphaherpesviruses. Vet Microbiol. 2014;169(1-2):50-7.

24. Allen GP, Breathnach CC. Quantification by real-time PCR of the magnitude and duration of leucocyte-associated viraemia in horses infected with neuropathogenic vs. non-neuropathogenic strains of EHV-1. Equine Vet J. 2006;38(3):252-7.

25. Stasiak K, Dunowska M, Hills SF, Rola J. Genetic characterization of equid herpesvirus type 1 from cases of abortion in Poland. Arch Virol. 2017;162(8): 2329-35.

26. Malik P, Balint A, Dan A, Palfi V. Molecular characterisation of the ORF68 region of equine herpesvirus-1 strains isolated from aborted fetuses in Hungary between 1977 and 2008. Acta Vet Hung. 2012;60(1):175-87.

27. Garvey M, Lyons R, Hector RD, Walsh C, Arkins S, Cullinane A: Molecular Characterisation of Equine Herpesvirus 1 Isolates from Cases of Abortion, Respiratory and Neurological Disease in Ireland between 1990 and 2017. Pathogens 2019, 8(1):7.

28. Sutton G, Garvey M, Cullinane A, Jourdan M, Fortier C, Moreau P, et al. Molecular surveillance of EHV-1 strains circulating in France during and after the major 2009 outbreak in Normandy involving respiratory infection, neurological disorder, and abortion. Viruses. 2019;11(10):916.

29. Diallo IS, Hewitson G, Wright LL, Kelly MA, Rodwell BJ, Corney BG. Multiplex real-time PCR for the detection and differentiation of equid herpesvirus 1 (EHV-1) and equid herpesvirus 4 (EHV-4). Vet Microbiol. 2007;123(1-3):93-103.

30. Stasiak K, Dunowska M, Rola J. Prevalence and sequence analysis of equid herpesviruses from the respiratory tract of polish horses. Virol J. 2018;15(1):106.
31. Kimura M. A simple method for estimating evolutionary rates of base substitutions through comparative studies of nucleotide sequences. J Mol Evol. 1980;16:111-20.

32. Kumar S, Stecher G, Tamura K. MEGA7: molecular evolutionary genetics analysis version 7.0 for bigger datasets. Mol Biol Evol. 2016;33:1870-4.

33. Cullinane A. Equine rhinopneumonitis (infection with equid herpesvirus-1 and -4). In: Manual of Diagnositc Tests and Vaccines for Terrestial Animals 2019: OIE World Organisation for Animal Health; 2019. Available from: http://www.oie.int/standard-setting/terrestrial-manual/access-online/.

34. Smith KC, Blunden AS, Whitwell KE, Dunn KA, Wales AD. A survey of equine abortion, stillbirth and neonatal death in the UK from 1988 to 1997. Equine Vet J. 2003:35(5):496-501.

35. Smith KC, Mumford JA, Lakhani K. A comparison of equid herpesvirus-1 (EHV-1) vascular lesions in the early versus late pregnant equine uterus. J Comp Pathol. 1996;114(3):231-47.

36. Edington N, Smyth B, Griffiths L. The role of endothelial cell infection in the endometrium, placenta and foetus of equid herpesvirus 1 (EHV-1) abortions. J Comp Pathol. 1991;104(4):379-87.

37. Edington N, Bridges CG, Patel JR. Endothelial cell infection and thrombosis in paralysis caused by equid herpesvirus-1: equine stroke. Arch Virol. 1986; 90(1-2):111-24

38. Lunn DP, Davis-Poynter N, Flaminio MJBF, Horohov DW, Osterrieder K, Pusterla $\mathrm{N}$, et al. Equine Herpesvirus-1 consensus statement. J Vet Intern Med. 2009;23(3):450-61.

39. Noronha LE, Antczak DF. Modulation of T-cell reactivity during equine pregnancy is antigen independent. Am J Reprod Immunol. 2012;68(2):107-15.

40. Perkins GA, Goodman LB, Dubovi EJ, Kim SG, Osterrieder N. Detection of equine herpesvirus-1 in nasal swabs of horses by quantitative real-time PCR. Jet Intern Med. 2008;22(5):1234-8.

41. Gibson JS, Slater JD, Awan AR, Field HJ. Pathogenesis of equine herpesvirus1 in specific pathogen-free foals: primary and secondary infections and reactivation. Arch Virol. 1992;123(3-4):351-66.

42. Soboll G, Hussey SB, Whalley JM, Allen GP, Koen MT, Santucci N, et al. Antibody and cellular immune responses following DNA vaccination and EHV-1 infection of ponies. Vet Immunol Immunopathol. 2006; 111(1-2):81-95.

43. Foote CE, Gilkerson JR, Whalley JM, Love DN. Seroprevalence of equine herpesvirus 1 in mares and foals on a large Hunter Valley stud farm in years pre- and postvaccination. Aust Vet J. 2003;81(5):283-8.

44. Gilkerson JR, Whalley JM, Drummer HE, Studdert MJ, Love DN. Epidemiology of EHV-1 and EHV-4 in the mare and foal populations on a Hunter Valley stud farm: are mares the source of EHV-1 for unweaned foals. Vet Microbiol. 1999;68(1-2):27-34.

45. Gilkerson JR, Whalley JM, Drummer HE, Studdert MJ, Love DN. Epidemiological studies of equine herpesvirus 1 (EHV-1) in thoroughbred foals: a review of studies conducted in the Hunter Valley of New South Wales between 1995 and 1997. Vet Microbiol. 1999;68(1-2):15-25.

46. Bresgen C, Lammer M, Wagner B, Osterrieder N, Damiani AM. Serological responses and clinical outcome after vaccination of mares and foals with equine herpesvirus type 1 and 4 (EHV-1 and EHV-4) vaccines. Vet Microbiol. 2012;160(1-2):9-16.

47. Kydd JH, Townsend HG, Hannant D. The equine immune response to equine herpesvirus-1: the virus and its vaccines. Vet Immunol Immunopathol. 2006;111(1-2):15-30.

48. Goehring LS, Wagner B, Bigbie R, Hussey SB, Rao S, Morley PS, et al. Control of EHV-1 viremia and nasal shedding by commercial vaccines. Vaccine. 2010;28(32):5203-11.

49. Burki F, Rossmanith W, Nowotny N, Pallan C, Mostl K, Lussy H. Viraemia and abortions are not prevented by two commercial equine herpesvirus-1 vaccines after experimental challenge of horses. Vet Q. 1990;12(2):80-6.

50. Goehring LS, Landolt GA, Morley PS. Detection and Management of an Outbreak of equine Herpesvirus type 1 infection and associated neurological disease in a veterinary teaching hospital. J Vet Intern Med. 2010;24(5):1176-83.

51. Burgess BA, Tokateloff N, Manning S, Lohmann K, Lunn DP, Hussey SB, et al. Nasal shedding of equine herpesvirus-1 from horses in an outbreak of equine herpes myeloencephalopathy in Western Canada. J Vet Intern Med. 2012;26(2):384-92

52. Goehring LS, van Maanen C, Berendsen M, Cullinane A, de Groot RJ, Rottier PJ, et al. Sloet van Oldruitenborgh-Oosterbaan MM: experimental infection 
with neuropathogenic equid herpesvirus type 1 (EHV-1) in adult horses. Vet J. 2010;186(2):180-7.

53. Mumford JA, Rossdale PD, Jessett DM, Gann SJ, Ousey J, Cook RF. Serological and virological investigations of an equid herpesvirus 1 (EHV-1) abortion storm on a stud farm in 1985. J Reprod Fertil Suppl. 1987;35:509-18.

54. Crabb BS, Studdert MJ. Equine herpesviruses 4 (equine rhinopneumonitis virus) and 1 (equine abortion virus). Adv Virus Res. 1995;45:153-90

55. Allen GP. Risk factors for development of neurologic disease after experimental exposure to equine herpesvirus-1 in horses. Am J Vet Res. 2008;69(12):1595-600.

56. Kydd JH, Wattrang E, Hannant D. Pre-infection frequencies of equine herpesvirus-1 specific, cytotoxic T lymphocytes correlate with protection against abortion following experimental infection of pregnant mares. Vet Immunol Immunopathol. 2003;96(3-4):207-17.

57. Matczuk AK, Skarbek M, Jackulak NA, Bazanow BA. Molecular characterisation of equid alphaherpesvirus 1 strains isolated from aborted fetuses in Poland. Virol J. 2018;15(1):186.

58. Bryant NA, Wilkie GS, Russell CA, Compston L, Grafham D, Clissold L, et al. Genetic diversity of equine herpesvirus 1 isolated from neurological, abortigenic and respiratory disease outbreaks. Transbound Emerg Dis. 2018; 65(3):817-32.

\section{Publisher's Note}

Springer Nature remains neutral with regard to jurisdictional claims in published maps and institutional affiliations.

Ready to submit your research? Choose BMC and benefit from:

- fast, convenient online submission

- thorough peer review by experienced researchers in your field

- rapid publication on acceptance

- support for research data, including large and complex data types

- gold Open Access which fosters wider collaboration and increased citations

- maximum visibility for your research: over $100 \mathrm{M}$ website views per year

At $\mathrm{BMC}$, research is always in progress.

Learn more biomedcentral.com/submissions 